\title{
O ESPAÇO DE REPRESENTAÇÃO DO FUTEBOL: UMA APREENSÃO DO FUTEBOL COMO UM ELEMENTO SOCIOCULTURAL E ESPACIAL ${ }^{1}$ \\ The football representational space: a view of football as a social-cultural and spatial element
}

\author{
Fernando Rosseto Gallego CAMPOS 2
}

\section{RESUMO}

O presente trabalho tem como objetivo desenvolver um corpo teórico-conceitual que possibilite que o futebol seja estudado como um elemento sociocultural e espacial. Propõe-se um diálogo entre a abordagem cultural em geografia, a teoria das representações sociais de Moscovici (2003) e as formulações sobre o espaço de representação de Lefébvre (1991), Soja (1996) e Gil Filho (2003). Foi a partir de uma leitura das idéias destes autores que se formulou o conceito de espaço de representação do futebol, composto por diversos elementos, que se dividem em categorias centrais (fato futebolístico, prática social do futebol e poder), categorias de mediação (símbolo, mito moderno, discurso, identidade futebolística) e reinos (política institucional, ethos futebolístico e paixão/afetividade).

\section{Palavras-chave:}

Espaço de representação; representações sociais; espaço de representação do futebol.

\begin{abstract}
This paper aims at developing a conceptual-theorical body which makes possible study football as social-cultural and spacial element. A dialogue between the cultural board in geography is proposed and also, the Moscovici's (2003) social representational theory and the Lefébvre's (1991) formulations about the representational space, Soja (1996) and Gil Filho (2003). It was from a lecture of the ideas of these authors which formulated the concept of the football representational space, compounded by several elements, split into central categories (footballing fact, social practice of football and power), mediational categories (symbol, modern myth, speech, footballing identity) and kingdoms (institucional politics, footballing ethos and passion/affection).
\end{abstract}

\section{Key-words:}

Representational space; social representations; football representational space.

1 Artigo originado da dissertação de mestrado "A construção do espaço de representação do futebol, em Curitiba-PR".

2 Graduado em Geografia UTP, Graduado em Comunicação Social - Jornalismo UFPR, Mestre em Geografia UFPR - E-mail: fgallego@gmail.com 


\section{INTRODUÇÃO}

O futebol é um elemento essencial da cultura brasileira, pois não apenas ajudou (e continua ajudando) na construção de uma identidade brasileira como está presente na vida cotidiana dos habitantes. Ele é praticado, assistido, acompanhado, comentado e interpretado pelos indivíduos. Transcende, assim, sua qualidade esportiva, tornando-se um importante elemento sociocultural e espacial. Deste modo, é possível e necessário que seja estudado pela ciência geográfica.

O objetivo deste artigo é desenvolver um corpo teórico-conceitual que possibilite que o futebol seja estudado como um elemento sociocultural e espacial. O futebol diz muito sobre o país e seus habitantes, sobre os costumes, sentimentos, relações e idéias através de representações sociais. Ele constitui uma instância própria da espacialidade, o espaço de representação do futebol. Este conceito possibilita a apreensão deste tema pela geografia.

Primeiramente, será realizada uma discussão teórica acerca da abordagem cultural em geografia, bem como das teorias que servem de base para este artigo. Tais teorias são: das representações sociais, de Moscovici (2003), e do espaço de representação, a partir das formulações de Lefébvre (1991), Soja (1993 e 1996) e Gil Filho (2003). Posteriormente, a fim de formular o conceito inédito, serão apresentados e discutidos os atores socioespaciais - profissionais, especialistas e torcedores - e elementos do espaço de representação do futebol - prática social do futebol, fato futebolístico, poder, discurso, símbolo, mito moderno, identidade futebolística, política institucional, ethos futebolístico e paixão/afetividade.

\section{FUNDAMENTAÇÃO TEÓRICA E CONCEITUAL}

O futebol é um importante elemento da sociedade e da cultura brasileiras. Ele não se limita a ser um esporte, mas se constitui numa relevante manifestação sociocultural, construtora de espacialidade. Nesta, os atores socioespaciais se relacionam e produzem representações sociais. Desta forma, o futebol influencia a vida cotidiana das pessoas, que projetam nele suas alegrias, frustrações e expectativas. O futebol também é um importante elemento na vida política do país, pois seus elementos simbólicos muitas vezes são apropriados pelos governos. O aproveitamento da catarse produzida pela conquista da Copa do Mundo de 1970 para legitimar a ditadura militar é um exemplo disto. Nas últimas décadas, o futebol se tornou um negócio lucrativo, que promove a circulação de centenas de milhões de dólares anualmente no mundo. Além disto, ele é um importante construtor de relações sociais e elemento de constituição de uma identidade nacional. No entanto, não recebe a atenção necessária da academia, sobretudo, da geografia. Esta discussão teórica visa a elaboração de um corpo conceitual capaz de estudar o futebol como elemento espacial. O desenvolvimento do conceito de espaço de representação do futebol - instância da espacialidade própria do futebol - é uma alternativa para que o tema seja estudado sob um olhar geográfico.

A fim de elaborar este conceito, propõe-se uma aproximação da abordagem cultural em geografia com a teoria das representações sociais, de Moscovici (2003); com as formulações sobre espaço de representação de Lefébvre (1991), Soja (1993 e 1996) e Gil Filho (2003).

A renovação da geografia cultural e sua revigoração, a partir dos anos 1980 , se baseia na crítica das limitações dos estudos tradicionais - das escolas alemã, francesa e estadunidense. A nova abordagem cultural em geografia procura romper com o positivismo e se aproximar de uma abordagem cultural humanista. Passa, assim, a incorporar fatores subjetivos, dando grande importância para a comunicação e para os indivíduos. O positivismo, na geografia cultural, impedia o estudo das idéias e das representações, destacando apenas os aspectos materiais da cultura (CLAVAL, 1999). Além disso, a cultura era utilizada como fator explicativo somente em última instância, quando se esgotavam quaisquer outras possibilidades para justificar uma distribuição espacial.

Aspectos materiais continuam fazendo parte dos trabalhos, mas em outro contexto. Deixam de ser a única forma de se explicar as relações culturais e passam a ser estudadas junto dos aspectos cognitivos, das atividades mentais e das trocas de informações e idéias. Assim, ganham espaço os aspectos não-materiais e simbólicos. Desta forma, é necessário pensar alternativas metodológicas para a abordagem cultural em geografia, que não apenas permite, mas também pede novas abordagens: "as técnicas tornaram-se demasiadamente uniformes para deter a atenção; são representações, negligenciadas até então, que merecem ser estudadas" (CLAVAL, 2001, p. 50). O estudo das representações vai ao encontro das novas tendências e pode ser uma saída interessante para os problemas operacionais do conceito de cultura.

Ao mesmo tempo em que a concepção de cultura se enriquece, adicionando elementos subjetivos aos aspectos materiais e ganhando um caráter mais dinâmico e aberto, ela se torna pouco operacional; pretende dar conta de tudo, comprometendo sua utilização prática. A teoria das representações sociais concebe um universo 
consensual - onde ocorrem as relações cotidianas, no qual a cultura circula, se modifica, se difunde e influencia a vida das pessoas - em oposição a um reificado - o universo institucional.

A teoria das representações sociais está inserida dentro do ramo da psicologia social, que se aproxima da sociologia e da antropologia. Sua origem está ligada às representações coletivas de Durkheim, que, segundo Moscovici (2001), são um instrumento explanatório que se referem a uma classe geral de idéias e crenças (abarcam uma cadeia completa de formas intelectuais que incluem ciência, religião, mito, modalidades de tempo e espaço, etc). As representações coletivas apresentam problemas operacionais, pois são estanques. Já as representações sociais devem ser vistas como uma maneira específica de compreender e comunicar o que se sabe. Reproduzem o mundo de forma significativa, pois cada representação é acompanhada de uma imagem e de uma significação simbólica.

As representações sociais são a forma pela qual as pessoas compreendem a realidade, sendo sua finalidade "tornar familiar algo não-familiar, ou a própria não familiaridade" (MOSCOVICl, 2003, p. 54). Isto se dá pelos processos de ancoragem e objetivação. A ancoragem consiste em classificar e nomear alguma coisa, fazer com que idéias estranhas se tornem categorias comuns a partir de paradigmas já existentes e, ainda, atribuir valor. Já a objetivação ocorre pela transformação de algo abstrato em algo quase concreto, pela transferência do que está na mente para algo que exista no mundo físico, pela transformação da palavra que substitui a coisa, na coisa que substitui a palavra (MOSCOVICl, 2003).

As representações estão presentes em todas manifestações da cultura na sociedade: "todas as interações humanas, surjam elas entre duas pessoas ou entre dois grupos, pressupõem representações" (MOSCOVICl, 2003, p. 40).

Capazes de influenciar comportamentos, são criadas internamente, não por um indivíduo isolado, mas dentro de um contexto social. Uma vez criadas, ganham vida própria, circulam, se atraem e se repelem e dão oportunidade ao nascimento de novas representações, enquanto as antigas morrem.

O conceito de representações sociais, uma forma de conhecimento da realidade nas relações cotidianas, vai ao encontro das novas tendências da abordagem cultural em geografia, pois contempla as modificações internas e externas nas culturas. Se a cultura circula e se modifica nas relações entre os indivíduos em uma sociedade, uma teoria que dê conta da cotidianidade pode suprir as necessidades da abordagem cultural em geografia.
Partindo do pressuposto que a cultura está presente nas relações cotidianas - apesar de não se limitar a elas - o uso do conceito de representações sociais para o estudo de tais relações se demonstra mais operacional do que o conceito de cultura. Não se está propondo uma substituição de termos, mas se advertindo para a utilização do conceito de representações sociais, deixando o de cultura como pano de fundo. A nova concepção de cultura nortearia as pesquisas geográficas, enquanto a teoria das representações sociais forneceria os instrumentos para o estudo das relações cotidianas referentes à cultura. Não se deixaria de estudar a cultura, mas sim se abordaria a mesma nas relações cotidianas de representações.

Para que a aproximação entre a abordagem cultural em geografia e a teoria das representações sociais se dê de forma efetiva e proveitosa para a ciência geográfica, é preciso utilizar um conceito-chave derivado das categorias centrais da geografia. Propõe-se, então a utilização do conceito de espaço de representação, formulado inicialmente por Lefébvre, em diálogo com a teoria das representações sociais de Moscovici.

Lefébvre (1991) defende a idéia de que o espaço não é algo já dado, mas sim produzido. Em sua obra, atribui grande importância à organização espacial como produto social, o que inspira as formulações de Edward Soja sobre a dialética socioespacial. Este procura incorporar a discussão espacial na tradicional dialética marxista, na qual a história tem papel fundamental. Soja (1993, p. 102-103) aponta, a partir de uma citação de Lefébvre, as premissas básicas de sua dialética:

que as relações sociais e espaciais são dialeticamente inter-reativas, interdependentes; que as relações sociais de produção são formadoras do espaço e contingentes ao espaço.

Em "The Production of Space" (1991), Lefébvre apresenta uma discussão sobre o espaço social, sendo ponto fundamental de tal debate a divisão do espaço em três componentes coexistentes. O espaço de representação é um destes componentes, que formam o que Soja (1996), ao analisar a obra de Lefébvre, chama de trialética do espaço. Esta tríade é formada pelo: espaço percebido - o espaço das práticas sociais (spatial practice), das relações materiais da espacialidade social; espaço concebido (representations of space) - é o espaço das instituições, onde ocorrem as representações do espaço produzidas pelas relações de poder, que influenciam a percepção espacial; e o espaço vivido (representational spaces) - que é o espaço de representação, no qual o ser humano se auto-representa a fim de buscar seu prazer e autenticidade, esquivando-se do espaço concebido. 
O espaço de representação é simbólico. Nele os significados atribuídos aos objetos podem ser modificados em relação ao espaço físico. Geralmente, estes símbolos e signos fazem parte de um sistema mais ou menos coerente. Lefébvfre escreve sobre o espaço de representação:

\begin{abstract}
Space as directly lived through its associated images and symbols, and hence the space of 'inhabitants' and 'users', but also of some artists and perhaps of those, such as a few writers and philosophers, who describe and aspire to do no more than describe. This is the dominated - and hence passively experienced - space which the imagination seeks to change and appropriate. It overlays physical space, making symbolic use of its objects. Thus representational spaces may be said, though again with certain exceptions, to tend towards more or less coherent systems of non-verbal symbols and signs. (LEFÉBVRE, 1991, p. 39)
\end{abstract}

Soja faz uma leitura da obra de Lefébvre em seu livro "Thirdspace" (1996). Nele, o autor procura apresentar as principais formulações do filósofo francês e, a partir delas, realizar suas próprias. Ao falar do espaço de representação, Soja o atribui à condição de conter simultaneamente, em seu interior, tanto o espaço real quanto o imaginário: "Combining the real and the imagined, things and thought on equal terms, or at least not privileging one over the other a priori" (SOJA, 1996, p. 68).

Segundo Sylvio Fausto Gil Filho (2003), o espaço de representação passa pelo espaço visível, mas é simbólico, tendo o atributo de projetar o ser no mundo. É através dele que o sujeito se contextualiza no mundo, se articulando com o espaço da prática social e suas relações materiais.

A origem do termo está ligada aos estudos sobre o caráter simbólico do regime nazista, pelo historiador Mosse. No entanto, foi utilizado por diferentes autores de diversas áreas, como Bettanini, Lefébvre e Soja. Os dois últimos foram os que desenvolveram tal categoria de forma que se tornasse possível a aproximação, através dela, da abordagem cultural em geografia à teoria das representações sociais.

Gil Filho realiza uma proposta epistemológica para o uso do espaço de representação como conceito chave para estudos da geografia cultural. Para ele:

O espaço de representação é o reino da esfera consensual, e a expressão da esfera reificada da consciência coletiva, o momento em que o atributo de ser uma coisa se torna típica da realidade objetiva. Sua prática cotidiana é a própria representação, e sua expressão é o condicionamento do poder exer- cido. O espaço de representação é um espaço vivo com ligações culturais, lócus da ação e das situações vivenciadas. É relacional em percepção, diferencialmente qualitativo e dinâmico e de natureza simbólica. (GIL FILHO, 2003, p. 5)

A categoria espaço de representação, conforme apresentado, é capaz de sustentar a teoria das representações sociais em uma perspectiva geográfica. Assim, contribui para que a abordagem cultural em geografia ganhe fôlego a partir da perspectiva da realização de um diálogo com a teoria das representações sociais. Deste modo, a cultura passa a exercer uma função norteadora (não mais de conceito chave), possibilitando que os trabalhos em geografia cultural se fundamentem na teoria das representações sociais e utilizem o espaço de representação como conceito chave.

\section{O ESPAÇO DE REPRESENTAÇÃO DO FUTEBOL}

O espaço de representação do futebol se estrutura através de diversos elementos - elaborados e apropriados, através de representações sociais, por diferentes atores socioespaciais - dispostos em círculos que se interagem entre si, formando complexas relações. Há o círculo dos reinos, das categorias de mediação e das categoriais centrais. Os reinos se manifestam enquanto representação social, já as categorias centrais, através de sua interação, produzem o conceito de espaço de representação. Elas se expressam através do círculo das categorias de mediação.

A partir do redimensionamento do espaço de representação realizado por Gil Filho (2003) - em seus estudos sobre geografia da religião - foi desenvolvida a estruturação do espaço de representação do futebol.

O espaço de representação do futebol se divide em três categorias centrais: o poder, o fato futebolístico e a prática social do futebol. Estas três categoriais centrais se relacionam com os três reinos (da política institucional, da paixão/afetividade e do ethos futebolísticos) através das quatro seguintes categoriais de mediação: o mito moderno, o discurso, a identidade futebolística e o símbolo. Ainter-relação de todos estes elementos constitui o espaço de representação do futebol (Figura 01).

\section{ATORES SOCIOESPACIAIS}

Toledo afirma que o futebol é "uma manifestação cultural que revela nosso jeito, malícia, alegria ou ginga, o futebol protagonizou os contornos de um processo de identificação construído e engendrado por esses diferen- 


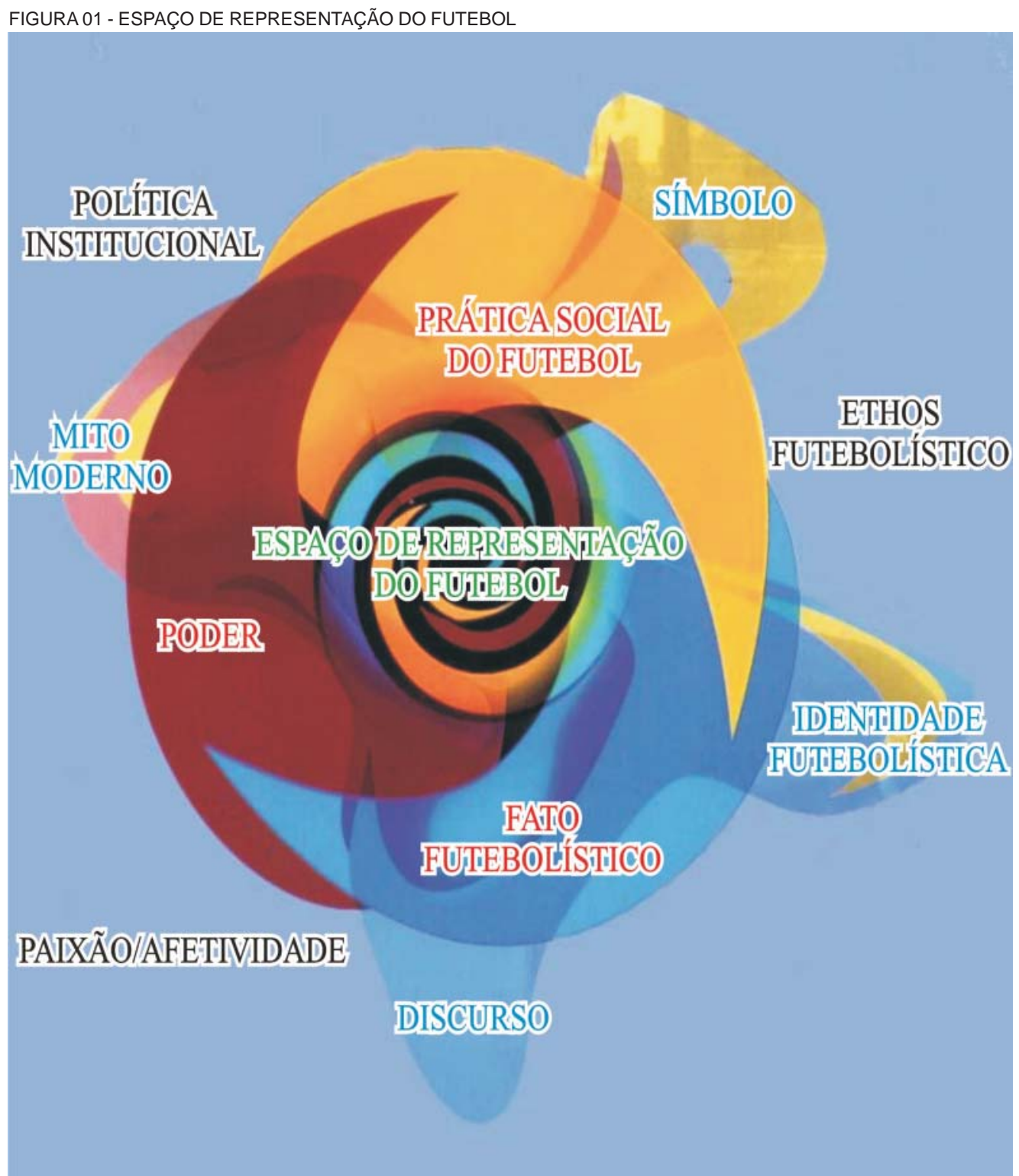

tes agentes sociais em interação" (TOLEDO, 2000, p. 08). A classificação dos atores socioespaciais do futebol utilizada como base para este artigo será a de Toledo (2002), que os divide em: profissionais, especialistas e torcedores. Tal divisão não pressupõe uma homogeneidade dentro destes grupos, mas que estes possuem certas características que os diferenciam dos demais, no que diz respeito às apropriações que fazem dos elementos do espaço de representação do futebol.

Os profissionais "serão todos aqueles que interferirem diretamente no jogo, quer dentro de campo, (...), quer na preparação dos jogadores, (...), ou no suporte administrativo dos dirigentes, (...)" (TOLEDO, 2002, p. 16). Portanto, tal categoria é composta por jogadores, técnicos, fisioterapeutas, médicos, massagistas, dirigentes, funcionários do clube, árbitros, empresários, entre outros profissionais ligados à performance do fato futebolístico.

No entanto, dentro deste grupo nem todos os atores socioespaciais exercem profissionalmente suas atividades. Diferente do caso dos jogadores, treinadores e demais membros da comissão técnica, os dirigentes dos clubes nem sempre são remunerados para executar suas funções. Os dirigentes, conhecidos no Brasil pelo nome de cartolas, são em sua maioria amadores, ou seja, se dedicam ao futebol paralelamente a sua atividade profissional (advogados, empresários, médicos, etc.). Estes são ligados aos clubes, na maioria dos casos, por 
uma identidade futebolística e pela afetividade. A prática amadora da atividade de dirigente, dita como maléfica à organização do clube e do próprio futebol brasileiro, está prevista no estatuto de muitos clubes, como Corinthians, Flamengo, Vasco e Grêmio (UNZELTE, 2002).

A categoria dos especialistas compreende a crônica esportiva em geral (narradores, comentaristas, repórteres, apresentadores, cinegrafistas, etc.). O nome "especialistas" deriva da expressão "imprensa especializada". Os especialistas - que trabalham na mídia não jogam nem torcem, ocupando uma posição entre a categoria dos profissionais e dos torcedores, como pode ser observado nas palavras de Toledo (2002, p. 17): "suponho que construam, no plano das representações, um lugar simbólico eqüidistante entre os profissionais e os torcedores. Não jogam, mas também não se comprometem no nível da emoção partidária, ao menos em tese, do mesmo modo que o conjunto de torcedores". Tal afirmação pressupõe a constante busca da objetividade na cobertura jornalística da mídia. Entende-se por objetividade "uma mistura de estilo direto, imparcialidade, fatualidade, isenção, neutralidade, distanciamento, alheamento em relação a valores e ideologia" (AMARAL, 1996, p. 26). Desta forma, não cabe ao jornalista tomar partido deliberadamente em relação a fatos da partida, por exemplo.

Todavia, o jornalismo esportivo apresenta peculiaridades. Diferentemente de outras áreas do jornalismo, ele mexe com a emoção das pessoas cotidianamente. Apesar de não ser a promoção do jogo a função do jornalismo esportivo, a espetacularização do futebol e sua apropriação pela mídia exige este expediente. Nota-se, assim, uma mistura entre jornalismo e espetáculo, entre notícia e promoção. Desta forma, os especialistas - através dos meios de comunicação - são formadores e difusores de representações sociais, que são apropriadas pelos profissionais e, sobretudo, pelos torcedores.

O terceiro grupo, o dos torcedores, é aquele formado por atores socioespaciais que se aglutinam em torno de uma instituição futebolística através de ligações afetivas e identitárias. A Seleção Brasileira é a instituição futebolística que possui maior importância simbólica na constituição do espaço de representação em nível nacional. Na escala local, os clubes são as instituições básicas do espaço de representação do futebol. Eles são o local de trabalho dos profissionais; objetos de cobertura jornalística dos especialistas; e instituições aglutinadoras de torcedores.

A partir dos clubes, se desenvolve uma complexa rede de relações socioespaciais, envolvendo os diferentes atores e instituições. No Brasil, eles estão vinculados a federações estaduais, que, por sua vez, formam uma confederação nacional (Confederação Brasileira de
Futebol - CBF). Esta é filiada a uma associação continental (sul-americana), que é submetida à Fifa (Fédération Internationale de Football Association), órgão máximo do futebol mundial.

\section{ELEMENTOS DO ESPAÇO DE REPRESENTAÇÃO DO FUTEBOL}

O futebol apresenta uma prática social própria, porém altamente articulada com a prática social cotidiana. Tal articulação se dá de maneira mais íntima em sociedades nas quais o futebol ocupa um espaço importante como elemento sociocultural e de sociabilização. No caso brasileiro, parte-se do pressuposto que a prática social do futebol é indissociável da prática social em sentido geral e vice-versa. A mobilização social em torno da Seleção Brasileira - símbolo maior do espaço de representação do futebol brasileiro - em época de Copa do Mundo, sobretudo, é um exemplo desta articulação. Em dia de jogo, funcionários são dispensados, os torcedores se reúnem em bares ou em suas próprias casas para assistir o jogo, a mídia só tem olhos para a partida e seus preparativos. Esta, talvez seja a manifestação mais bem acabada que o futebol faz realmente parte da prática social cotidiana do brasileiro, mas não é a única. A mobilização em torno dos jogos dos clubes, as conversas nos bares, as provocações a torcedores rivais também demonstram que o dia-adia dos brasileiros é permeado por representações sociais referentes ao futebol.

Dentro do contexto do espaço de representação do futebol, prática social do futebol são todas e quaisquer relações sociais produzidas pelo futebol. Vai desde o ir ao estádio, o jogar, o torcer, até os comentários produzidos pela partida e seus bastidores. Entender a prática social do futebol é passo fundamental para compreender a construção do espaço de representação do futebol, pois é nas relações cotidianas que vão circular, ser criadas e modificadas as representações sociais. Estas "são saberes sociais construídos em relação a um objeto social, que elas também ajudam a formar" (JOVCHELOVITCH, 2000, p. 32).

Segundo Berger e Luckmann (1999), a realidade social é construída objetiva e subjetivamente pelos indivíduos a partir de suas relações cotidianas. Como o futebol faz parte desta realidade, ele pode ser apreendido como, ao mesmo tempo, um produtor e um produto de representações sociais; através das quais o mundo cotidiano apresenta-se como coerente e dotado de sentido para os indivíduos. Estas são produzidas pelos pensamentos e ações dos atores socioespaciais, que partiIham uma realidade subjetivamente significativa. A prática social do futebol se organiza em torno do "aqui e ago- 
ra", ou seja, do espaço (o corpo) e do tempo (presente). O que está inserido neste recorte pode ser manipulado e apreendido pela consciência. O face a face constitui-se a base da interação social, pois os demais casos derivam deste. Portanto, o encontro de torcedores no estádio ou em espaços públicos (como bares, praças, etc.) é a situação mais propícia para o surgimento, modificações e circulações de representações sociais. Estas redefinem constantemente os elementos simbólicos do espaço de representação do futebol, bem como aspectos ligados à própria prática social do futebol, como os significados e formas de torcer.

Mas Berger e Luckmann (1999, p. 39) advertem que "a realidade da vida diária, porém, não se esgota nessas presenças imediatas, mas abraça fenômenos que não estão presentes aqui e agora'. Isto quer dizer que experimento a vida cotidiana em diferentes graus de aproximação e distância, espacial e temporalmente. A mais próxima de mim é a zona da vida cotidiana diretamente acessível à minha manipulação corporal". Neste sentido, as representações sociais são geradas e modificadas pelos atores socioespaciais não apenas no contato direto entre eles, mas também através de mediações, como o discurso dos especialistas, incorporado por torcedores. Constantemente, estes passam a elogiar ou criticar determinado jogador porque a mídia fez comentários positivos ou negativos sobre ele. Em muitos casos, o torcedor nem viu o jogador atuando e, decorrente ao discurso da mídia, incorporou uma série de representações sociais de que aquele jogador é péssimo, que não pode mais jogar no seu time, etc.

A própria transmissão de uma partida, seja pelo rádio ou pela televisão, é assimilada pelo torcedor através de representações sociais formuladas pelos especialistas. A televisão, através dos cortes de câmera, mostra uma das maneiras possíveis de se ver o jogo, bem como produz narração e comentários, que induzem à criação de representações sociais consoantes com a visão dos especialistas. Tais representações sociais são incorporadas pelos torcedores e reproduzidas em seus discursos nos encontros públicos (nos bares, no trabaIho, etc.).

O fato futebolístico pode ser apontado como elemento original do espaço de representação do futebol, pois sem ele os outros não fariam sentido. Ele é o ritual, o espetáculo em si. É a partida e os eventos que a circundam. O fato futebolístico não se limita ao esporte pro- fissional, mas se estende à prática lúdica do jogo. A abordagem contempla os dois tipos de prática do futebol, pois eles estão intimamente ligados. No entanto, se toma como ponto de partida a prática profissional, pois ela influencia a prática lúdica, estabelecendo seus referenciais (GIULIANOTTI, 2002).

É a partir do fato futebolístico que os torcedores formulam as representações sociais, que os diferentes atores do espaço de representação se relacionam e produzem seus discursos, que os símbolos e mitos são gerados, enfim, que toda a malha de significados que permeia o futebol é criada.

No fato futebolístico é possível observar as diferentes funções ritualísticas que os atores socioespaciais possuem no espaço de representação do futebol, bem como territorialidades que constroem. Os profissionais participam diretamente do fato futebolístico, jogando, dirigindo os times, apitando o jogo, prestando assistência médica, etc. Eles ocupam uma territorialidade circunscrita ao campo de jogo, aos vestiários e às áreas técnicas ${ }^{3}$. Especificidades espaciais permeiam a atuação de cada um dos grupos de profissionais (jogadores, treinadores, etc.) e, inclusive, de cada indivíduo dentro da partida.

Dentro de campo - não especificamente dentro do campo de jogo - cada ator se posiciona e atua em um espaço diferente. O treinador, a comissão técnica e os jogadores reservas ficam restritos a atuar no banco de reservas, sendo proibidos de entrar no campo de jogo sem autorização. No entanto, o treinador pode utilizar uma área exclusiva sua, denominada de área técnica. $\mathrm{O}$ árbitro principal apita a partida de dentro do campo, já seus dois auxiliares observam o jogo cada um de um lado do campo, porém fora de seus limites. Os 22 jogadores disputam a partida dentro dos limites do campo, entretanto os jogadores têm uma espacialidade restringida dentro destes limites devido à sua função tática e às regras. A função tática de um zagueiro central não o permite estar constantemente no campo de ataque, apenas em situações especiais, como em escanteios, faltas ou uma contingência da partida. Já o goleiro tem sua espacialidade restrita pela regra, pois só pode atuar como tal - realizando intervenções com as mãos - dentro de sua própria área.

Esta espacialidade ritualística dos profissionais contrasta com a prática social cotidiana, que, geralmente, não é feita nos estádios onde são praticados os jogos, mas em campos de treinamento, academias, pisci-

${ }^{3} \mathrm{~A}$ International Board - órgão vinculado à Fifa que postula sobre as leis do futebol - permite que o técnico levante do banco de reservas para orientar seu time, desde que permaneça dentro de um limite estipulado, denominado área técnica. Sua localização e suas dimensões podem variar de estádio para estádio, mas ela deve se estender a um metro de cada lado do banco e adiante até a distância de um metro da linha lateral. 
nas, entre outros locais nos quais os profissionais treinam, simulam as condições do fato futebolístico, se preparam ou se recuperam física e psicologicamente.

Os demais atores socioespaciais também possuem territorialidades definidas em relação ao fato futebolístico e à prática social do futebol. A territorialidade dos especialistas pode variar de acordo com o veículo de comunicação (televisão, rádio, internet, jornal, revista, etc.). No entanto, todos eles têm como o evento mais significativo a partida em si, girando toda sua programação em torno dela. Por exemplo, em dias de jogos, a impressão da edição do jornal aguarda o término das partidas da rodada, enquanto em dias sem jogos o jornal roda mais cedo. Já outros veículos, que transmitem diretamente as partidas, como televisão e rádio, concentram sua atenção na transmissão do evento, um misto de jornalismo e espetáculo (de sons e imagens).

Na partida, a mídia possui uma territorialidade específica, geralmente se limitando às cabines de rádio, televisão ou salas de imprensa, bem como ao redor do gramado (repórteres) e até dentro do campo, realizando entrevistas antes do início e no término de cada tempo de jogo. A abrangência dos diferentes tipos de veículos de comunicação também é diferente. Geralmente, os jogos transmitidos pela televisão têm abrangência nacional, já os pelo rádio têm audiência local. Isto depende da partida em questão e da tecnologia à disposição.

A questão da territorialidade dentre os torcedores é facilmente observada no fato futebolístico. Eles ocupam as arquibancadas, cadeiras numeradas e camarotes. Tal setorização expressa também uma divisão social estimulada pelo preço do ingresso. Todavia, há torcedores que mesmo podendo ficar em camarotes preferem as arquibancadas pela atmosfera encontrada nelas, manifestando seu sentimento topofílico. Para Giulianotti (2002), a topofilia dos torcedores a estádios ou a setores destes não está necessariamente ligada ao conforto, à estética ou ao refinamento funcional.

Estas territorialidades também estão relacionadas ao tipo de torcedor em questão: comum ou organizado. ${ }^{4}$ Os torcedores organizados, geralmente, ocupam um lugar definido no estádio, ficando o torcedor comum com os demais lugares.

A questão espacial desta atmosfera não se limita à torcida de um mesmo time, se estendendo também à torcida adversária.
Os times rivais podem expressar entusiasmo e respeito mútuo antes ou depois dos jogos, mas uma oposição competitiva básica permanece durante o jogo. Uma forte rivalidade entre os dois grupos de torcedores é tipicamente maior que sua amizade. A organização espacial do campo, permitindo ou enfraquecendo essas relações, desempenha papel importante na construção da "atmosfera" (GIULIANOTTI, 2002, p. 97).

A territorialidade dos torcedores na prática social do futebol é influenciada pelos resultados dos clubes no fato futebolístico. Quando o clube vence, os torcedores estendem suas comemoração às ruas e bares, ficando mais tempo curtindo a vitória de seu time. Os bares inclusive são um espaço importante da sociabilidade dos torcedores. Este é um ponto de encontro tanto nos dias de jogos como em dias "comuns". É em espaços como bares, ruas e praças que o futebol é comentado pelos torcedores, sendo uma ocasião propícia para a criação e circulação de representações sociais. Conseqüentemente, nestes espaços as rivalidades são alimentadas e consolidadas: "culturalmente, os jogos dérbi ${ }^{5}$ se auto-promoviam; os torcedores rivais viviam, trabalhavam e se reuniam uns com os outros, discutindo, rindo e teorizando indefinidamente sobre os encontros passados e futuros" (GIULIANOTTI, 2002, p. 26).

O poder é fundamental na constituição do espaço de representação do futebol, pois ele permeia todas as relações, sejam elas promovidas no fato futebolístico ou na prática social do futebol (RAFFESTIN, 1993). Ele se materializa nas relações entre os diferentes atores do espaço de representação do futebol, formando representações sociais, símbolos, mitos modernos, valores, discursos, etc.

Segundo Foucault (1998) o poder é relacional, ou seja, sua existência pressupõe uma relação. As relações de poder são desiguais entre os indivíduos ou grupos que participam delas. O que não significa que o poder é algo exclusivamente maléfico e repressivo, mas que as relações, pautadas por ele, também podem ser benéficas e construtivas. O autor defende a idéia de que o poder não é algo que é possuído, mas algo que é exercido. Não há aqueles que detêm e aqueles que não detêm o poder, mas sim aqueles que o exercem e aqueles que sofrem suas ações. Porém, afirma que todos os indivíduos exercem e sofrem ações do poder:

\footnotetext{
${ }^{4} \mathrm{O}$ torcedor comum é aquele que não possui ligação com nenhuma instituição torcedora. Os torcedores organizados são grupos que se organizam através de uma instituição torcedora, no Brasil denominadas torcidas organizadas. As torcidas organizadas, geralmente, são quem puxam os gritos e animam a torcida, utilizando-se de baterias, uniformes, fogos e outros adereços (faixas, bexigas, bandeiras, etc.), enfim, organizam o torcer no fato futebolístico.

${ }^{5}$ Os dérbis são os jogos envolvendo clubes da mesma cidade. No Brasil, a palavra mais comum para indicar estes jogos é "clássico", apesar do conceito de clássico ser mais amplo, pois não se limita a times da mesma cidade, apenas clubes que apresentam rivalidade entre si.
} 
O poder deve ser analisado como algo que circula, ou melhor, como algo que só funciona em cadeia. Nunca está localizado aqui ou ali, nunca está nas mãos de alguns, nunca é apropriado como uma riqueza ou um bem. O poder funciona e se exerce em rede. Nas suas malhas os indivíduos não só circulam mas estão sempre em posição de exercer este poder e de sofrer sua ação; nunca são o alvo inerte e consentido do poder, são sempre centros de transmissão. Em outros termos, o poder não se aplica aos indivíduos, passa por eles. Não se trata de conceber o indivíduo como uma espécie de núcleo elementar, átomo primitivo, matéria múltipla e inerte que o poder golpearia e sobre o qual se aplicaria, submetendo os indivíduos e estraçalhando-os. Efetivamente, aquilo que faz com que o corpo, gestos, discursos e desejos sejam identificados e constituídos enquanto indivíduos é um dos primeiros efeitos do poder. Ou seja, o indivíduo não é o outro do poder: é um de seus primeiros efeitos. O indivíduo é um efeito do poder e simultaneamente, ou pelo próprio fato de ser o efeito, é seu centro de transmissão. O poder passa através do indivíduo que ele constituiu. (FOUCAULT, 1998, p. 183-184)

Os diferentes atores socioespaciais interagem entre si formando uma rede de relações socioespaciais a partir do futebol. Nesta rede, o poder é exercido de diversas maneiras entre as instituições e os atores socioespaciais. Mesmo entre atores de uma mesma categoria o poder está presente em qualquer relação. No caso dos profissionais, os treinadores exercem poder sobre os jogadores definindo a escalação do time, por exemplo. Em contrapartida, o sucesso do treinador depende do desempenho dos jogadores.

Desta forma, o poder pode ser apreendido como uma relação de força entre os atores socioespaciais e os indivíduos. "O poder não se dá, não se troca nem se retoma, mas se exerce, só existe em ação, como também da afirmação que o poder não é principalmente manutenção e reprodução das relações econômicas, mas acima de tudo uma relação de força" (FOUCAULT, 1998, p. 175).

O poder também pode ser observado nos diferentes tipos de relações que as instituições futebolísticas possuem entre si. Um clube pode manter diversos tipos de relações com outro, como a de parceria ou a de rivalidade. Invariavelmente, um clube será adversário de outro no fato futebolístico, mas há aqueles adversários mais tradicionais, aqueles com os quais se disputa uma hegemonia local (ou até mesmo em outras escalas). Os clubes da mesma cidade tendem a possuir uma rivalidade maior, como é o caso de Coritiba e Atlético-PR, Grêmio e Internacional, Cruzeiro e Atlético-MG, Corinthians e Palmeiras, Flamengo e Fluminense, entre outros. Os jogos entre estes clubes ganham o nome de "clássicos" e possuem uma importância simbólica muito grande no espaço de representação do futebol, pois envolvem todos os atores socioespaciais e explicitam diversas relações de poder. Em escala internacional, o jogo entre Brasil e Argentina não se limita ao fato futebolístico, mas representa uma disputa pela hegemonia (não só esportiva) da América do Sul.

As relações de poder ocorrem nas interações entre os universos reificado e consensual, e inclusive no interior de ambos. Elas produzem representações sociais que influenciam na maneira de se jogar, torcer, entender, discutir, enfim, de se relacionar com o futebol.

A prática social do futebol, o fato futebolístico e o poder, em interação, produzem símbolos, mitos modernos, discursos e identidades futebolísticas. Tais elementos são fundamentais na constituição do espaço de representação do futebol, pois são eles que vão produzir sentido e perpetuar o universo simbólico do futebol. Eles surgem e circulam como representações sociais nas relações cotidianas produzidas pelo futebol.

O discurso possui uma ligação íntima com o poder, pois é uma manifestação deste. Ele é produzido e circulado através de relações de poder, que por sua vez também dependem deste discurso para existir. O discurso pode ser entendido como a mediação entre fenômenos da realidade e o saber. Ele expressa este saber, uma construção de poder sobre fatos da realidade. Foucault (1998, p. 179) afirma que

em uma sociedade como a nossa, mas no fundo em qualquer sociedade, existem relações de poder múltiplas que atravessam, caracterizam e constituem o corpo social e que estas relações de poder não podem se dissociar, se estabelecer nem funcionar sem uma produção, uma acumulação, uma circulação e um funcionamento do discurso.

Os discursos produzidos no espaço de representação do futebol estão ligados aos papéis dos atores socioespaciais desta instância da espacialidade. Cada papel exige e produz uma certa prática discursiva (LECOURT, 1996). É certo que esta depende também do indivíduo que fala, mas é fundamental lembrar que o indivíduo está investido de um cargo, que dentro da estrutura do futebol e das relações de poder às quais está exposto, exige uma certa regularidade no discurso, ou seja, características semelhantes no que tange a relações e efeitos coercitivos sobre os sujeitos. Porém, o discurso no futebol não se limita àquele produzido dentro das instituições futebolísticas (o discurso dos dirigentes, jogadores, técnicos, etc.), mas se estende ao dos meios de comunicação (jornais, rádio, televisão, etc.) e ao produzido pelos torcedores - que incorporam elementos do universo reificado (institucional) através, principalmente, de sua relação com a mídia. 
São notáveis as diferenças entre discursos de torcedores e profissionais (jogadores, em específico). Observa-se uma regularidade entre os torcedores, que pautam suas falas (e também seus atos) na afetividade, na paixão, na identidade futebolística que mantém com o clube. Deixam florescer seus desejos de vitória de maneira exacerbada e passional, cobrando a mesma afetividade dos profissionais ("tem que ter amor à camisa"). Por outro lado, os jogadores - que geralmente possuem um repertório lingüístico mais limitado - pautam o discurso na rotina de trabalho, no profissionalismo e, eventualmente, na afetividade. Comemoram sucessos ou justificam fracassos através dos esquemas táticos, orientações do treinador ou até mesmo da sorte (ou da falta dela).

Os símbolos são elementos fundamentais para o entendimento do espaço de representação do futebol, pois este é repleto de relações simbólicas. Eles estão presentes nos comportamentos, sentimentos, desejos e atos dos diversos atores socioespaciais do espaço de representação. Desta forma, ignorá-los seria omitir uma parte importante da constituição do espaço e também da vida dos indivíduos. Segundo Chevalier e Gheerbrant (1988, p. xii), "seria pouco dizer que vivemos num mundo de símbolos - um mundo de símbolos vive em nós".

Através dos símbolos é possível desvelar manifestações do inconsciente, os motivos das ações, enfim, descobrir os aspectos mais íntimos que motivam as mais diversas relações.

Os símbolos são todo e qualquer artefato ligado ao futebol, como as cores dos clubes, suas camisas, distintivos, bandeiras, mascotes, etc. O símbolo vai além do significado do objeto em questão, estendendo-se ao sujeito. Assim, os significados dos símbolos não são universais e intemporais, pois estes dependem da cultura na qual estão emersos, da época que se trata, dos atores socioespaciais que se apropriam destes e das instituições (clubes, federações, seleções) que representam. Assim, o mesmo símbolo admite mais de uma significação, mais de uma interpretação. Estes símbolos podem mudar sutilmente de significado durante o tempo e através do espaço ou ainda em razão de quem se apropria deles. Todavia, as mudanças de significado não são rápidas nem simples. É certo que diferentes clubes partilham as mesmas cores e que estas podem ter significados diferentes para tais clubes. Mas, geralmente, os torcedores de um mesmo clube partilham de um repertório de significados para as cores do clube que não variam muito de torcedor para torcedor. É importante ressaltar que tais símbolos são capazes de representar um clube, uma seleção, um país, o próprio futebol, diversas emoções, etc. Estes elementos são fundamentais nas relações promovidas pelo futebol, pois são eles que dão significado ao espaço de representação do futebol.
A Seleção Brasileira, por si só, se constitui um grande símbolo da nação brasileira, denotando patriotismo, orgulho e identidade nacional. Esta instituição construiu diversos símbolos durante sua história, que foram e continuam sendo apropriados pelos atores socioespaciais. As cinco estrelas que carrega acima de seu distintivo demonstram as conquistas em copas do mundo. $\mathrm{O}$ seu uniforme - que lhe rendeu o apelido de "seleção canarinho", devido à cor da camisa - é internacionalmente conhecido. No entanto, nem sempre a Seleção Brasileira utilizou este uniforme - constituído por camisas amarelas, calções azuis e meiões brancos. A derrota em casa, na Copa de 1950, para o Uruguai foi tão traumática que a partir daquele episódio a seleção decidiu que mudaria um dos seus maiores símbolos, o uniforme - que era todo branco com detalhes azuis.

A derrota para o Uruguai, em pleno Maracanã, é tido como o mito fundandor da história de glórias da Seleção Brasileira (COSTA apud PERDIGÃO, 1986). A perda do título mundial em pleno território nacional fez com que cada copa do mundo se tornasse uma oportunidade (quase um dever) da seleção, ou melhor, do Brasil se mostrar capaz para o mundo.

Os mitos estão inseridos no pensamento simbólico. Cassirer atribui aos mitos a função de dar sentido à "realidade":

Deste ponto de vista, o mito, a arte, a linguagem e a ciência aparecem como símbolos: não no sentido de que designam na forma de imagem, na alegoria indicadora e explicadora, um real existente, mas sim, no sentido de que cada uma delas gera e parteja seu próprio mundo significativo. Neste domínio, apresenta-se este autodesdobramento do espírito, em virtude do qual só existe uma "realidade"; um Ser organizado e definido. Conseqüentemente, as formas simbólicas especiais não são imitações, e sim, órgãos dessa realidade, posto que, só por meio delas, o real pode converter-se em objeto de captação intelectual e, destarte, tornar-se visível para nós. (CASSIRER, 1992, p. 22)

Desta maneira, são as referências do passado do esporte, dos clubes ou das seleções. Eles são construídos através da mitificação de jogadores, treinadores, dirigentes, jornalistas, entre outros atores do espaço de representação do futebol. O mito possui um caráter aparentemente irracional e incoerente, apesar de possuir uma ligação com o pensamento lógico. Assim, não é possível intelectualizar o pensamento mítico, pois ele se fundamenta em elementos emocionais.

O entendimento do mito passa pelo entendimento dos ritos. Para Cassirer (2003, p. 43) "o rito é um elemento muito mais profundo e duradouro do que o mito na 
vida religiosa do homem". Ele é o elemento dramático ou teatral da vida religiosa, mas não apenas dela. O fato futebolístico é o rito e as referências do futebol são os mitos. Estes são, fundamentalmente, mitos modernos, pois se fundam em duas forças, que mesmo agindo juntas não são idênticas. Estas são: o culto ao herói - que se fundamenta nas palavras de Carlye - e o culto à raça - postulado por Gobineau (CASSIRER, 2003).

Pelé é um exemplo de mito moderno. A construção de sua figura como o maior jogador de futebol de todos os tempos e de atleta do século passa pelas etapas citadas por Cassirer: o culto aos seus feitos heróicos (vencer três copas do mundo, marcar mais de mil gols, etc.) e o culto à raça (pelo fato de ser brasileiro e simbolizar o melhor do melhor futebol do mundo) (Figura 02).

FIGURA 02 - PELÉ

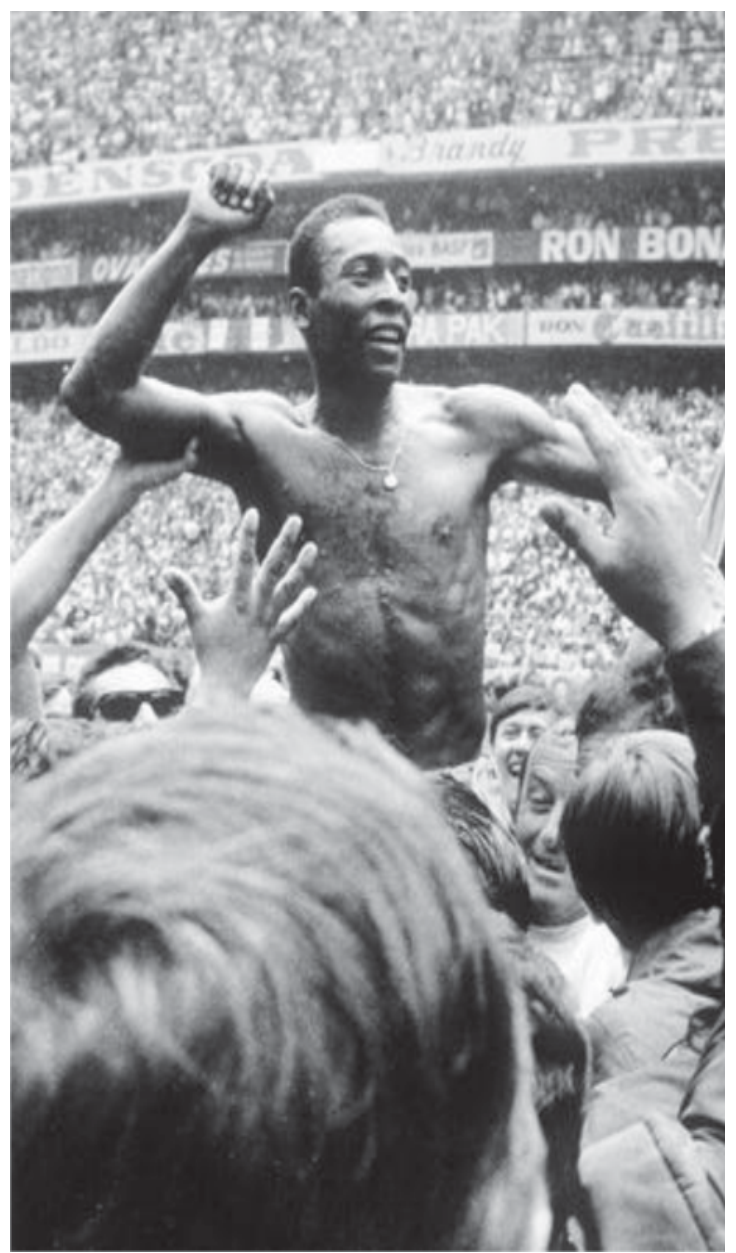

FONTE: SITE OFICIAL DA FIFA (DIREITOS RESERVADOS POPPERFOTO).

PELÉ É CARREGADO PELA MULTIDÃO, NO ESTÁDIO AZTECA, DEPOIS DE VENCER A COPA DE 1970 NO MÉXICO. CONSIDERADO O REI DO FUTEBOL, PELÉ CONQUISTAVA SUA TERCEIRA COPA.
Os mitos modernos são uma espécie de referência ou parâmetro aos quais os atuais atores socioespaciais devem se reportar e seguir como exemplo. Eles afloram em épocas em que o clube (ou instituição em questão) está encontrando dificuldades ou até mesmo quando grandes resultados no fato futebolístico fazem com que os atores socioespaciais se remetam ao passado.

Os mitos modernos do futebol são construídos através dos tempos por seus feitos. Desta forma, um torcedor jovem pode possuir mitos diferentes daquele torcedor com mais idade. Geralmente, o torcedor mais antigo tem mais dificuldade em aceitar como referência à história de seu time um jogador mais recente, o que muitas vezes não é um problema para o torcedor jovem.

O conceito de identidade adotado é o de Castells (2002). Este autor entende por

identidade o processo de construção de significados com base em atributo cultural, ou ainda um conjunto de atributos culturais inter-relacionados, o(s) qual(is) prevalece $(\mathrm{m})$ sobre outras fontes de significados (CASTELLS, 2002, p. 22).

Desta forma, atribui peso determinante à cultura na construção de identidades. Partindo do pressuposto de que as identidades são construídas socialmente e se dão no cotidiano, a partir de atributos culturais, é possível dizer que as identidades podem se constituir e se expressar através de representações sociais. Assim, as identidades reagem à estrutura social, remodelando-a constantemente. Quando Castells fala no prevalecimento de significados sobre outros se aproxima da fala de Moscovici (2003) ao dizer que as representações reproduzem o mundo de forma significativa e ao circular permitem o aparecimento de novas representações sociais com diferentes significados.

A identidade pode ser construída através da história, geografia, instituições, fantasias, por relações de poder, entre outros fatores. As representações sociais fornecidas por estes diversos elementos

são processados pelos indivíduos, grupos sociais e sociedades, que reorganizam seu significado em função de tendências sociais e projetos culturais enraizados em sua estrutura social, bem como em sua visão de tempo/espaço (CASTELLS, 2002, p. 23).

A identidade não passa apenas pelo processo de inclusão, mas também de exclusão - manifestado pela oposição ao outro. Identificar-se com um grupo que compartilha atributos culturais e representações sociais cujos significados são antagônicos aos de um outro grupo, é se opor a este grupo. Esta situação ocorre na constitui- 
ção dos nacionalismos, em oposição aos estrangeiros. O autoconhecimento de um grupo "nunca está totalmente dissociado da necessidade de ser conhecido, de modos específicos, pelos outros" (CALHOUN apud CASTELLS, 2002, p. 22), ou seja, passa pelas representações sociais construídas pelos outros.

A identidade futebolística permeia os três elementos citados anteriormente, pois é através dela que os torcedores se "aglutinam" socialmente em torno de um clube. Ela está ligada com o compartilhamento de representações sociais, que geram um sentimento de pertença. Os indivíduos que possuem representações sociais em comum formam as torcidas, que têm por característica a negação de outros clubes. Portanto, a identidade futebolística não se resume apenas a se identificar com um clube, mas também de negar os demais, principalmente os rivais. A rivalidade é um sentimento ligado às representações sociais compartilhadas por um grupo em oposição às compartilhadas por outro. Ela pressupõe a existência de um clube contrário. Em Curitiba, a maior rivalidade é entre Atlético Paranaense e Coritiba (o denominado Atletiba).

Todavia, a identidade futebolística não é exclusiva aos torcedores, podendo também ser observada nos demais atores socioespaciais do espaço de representação do futebol. Profissionais que se mantêm muito tempo em um clube ou que realizam feitos marcantes (conquista de títulos, etc.) também criam uma identificação grande com a instituição e com seus atores socioespaciais (sobretudo, torcedores). Vários jogadores são associados a clubes devido à identidade futebolística que mantêm com estas instituições. Alguns exemplos são: Pelé, com o Santos; Nilton Santos, com o Botafogo, etc. Atualmente, este processo de identificação dos jogadores com o clube é mais raramente observado, pois a dinâmica do mercado de transferência faz com que a tendência seja que o jogador constantemente troque de clube. Um exemplo disto é o centro-avante Luizão, que já defendeu mais de dez clubes em sua carreira e só em 2005 atuou por três diferentes (São Paulo, Nagoya Grampus-JAP e Santos). Em contrapartida, há alguns casos, mesmo que isolados, de enorme identificação futebolística nos tempos atuais, como ocorre com o goleiro Rogério Ceni, que está no São Paulo desde 1990 e é o jogador que mais atuou pelo tricolor paulista.

Estas categorias apresentadas, em interação, articulam os três reinos já citados. É importante ressaltar que quanto mais os elementos do espaço de representação do futebol se distanciam do centro do fractal (Figura 01), mais indireta torna sua relação com o próprio espaço de representação do futebol.
O reino da política institucional é aquele no qual as instituições futebolísticas interagem através de relações de poder. Tais relações são fundamentalmente políticas, pois é a partir delas que os indivíduos e grupos se diferenciam dos outros e que as organizações mantêm (ou procuram manter) sua ordem interna. Raffestin (1993, p. 34) deixa clara sua influência em Foucault, ao afirmar que:

nossa concepção é tão pouco econômica que colocaremos como axioma de base que toda relação, no que se refere ao seu conteúdo, é 'política', visto interessar e concernir realmente, ou virtualmente, a todo ser que pertence à coletividade ou a uma dada coletividade.

Desta forma, é possível afirmar que "o poder político é congruente a toda forma de organização" (RAFFESTIN, 1993, p.18).

O processo de institucionalização é fruto de relações entre atores sociais, de relações de poder e de representações sociais. As instituições são construídas a partir de uma historicidade compartilhada. O mundo institucional precede o nascimento do indivíduo e permanecerá depois de sua morte. Elas têm histórias próprias - construídas por indivíduos em um processo social -, as quais precisam ser compreendidas para ser possível entender adequadamente uma instituição. Algumas instituições que constituem o espaço de representação do futebol que podem ser citadas como exemplo são os clubes, as federações, as confederações, as torcidas organizadas, as instituições públicas, entre outras. A tradição é extremamente valorizada no espaço de representação do futebol. É comum ouvir os especialistas dizerem que determinado clube ganhou a partida porque "jogou com a camisa", ou seja, fez valer a sua maior tradição sobre o adversário. A Seleção Brasileira carrega uma tradição, que simbolicamente influencia no fato futebolístico.

Este reino é fragmentado e desigual em suas relações entre os atores que o constituem. Assemelha-se com o que Moscovici (2003, p. 51) denomina de universo reificado, no qual "a sociedade é vista como um sistema de diferentes papéis e classes, cujos membros são desiguais". É no reino da política institucional que são tomadas as decisões sobre o clube, seleção, regras, etc. Porém, tais decisões não ficam apenas circunscritas a este reino, podendo sofrer influências externas, como do reino da paixão/afetividade.

A articulação entre as instituições futebolísticas é um exemplo de como se estrutura este reino. A Fifa, entidade máxima do futebol, entre outras atribuições, define as regras do futebol - através de um órgão chamado International Board. Desta maneira, através de sua políti- 
ca institucional, exerce influências diretas e indiretas sobre o fato futebolístico e a prática social do futebol. As regras limitam as possibilidades de atuação dos jogadores e times dentro de campo (como ocorre com a lei do impedimento). Conseqüentemente, influenciam nos esquemas táticos adotados, bem como na estética do jogo. Esta varia de lugar para lugar através de representações sociais e elementos culturais incorporados. Por exemplo, a estética valorizada no futebol brasileiro (drible, flexibilidade tática, etc.) é condicionada pela regra do jogo, mas também é influenciada por representações sociais referentes à cultura brasileira. Se não fosse assim, o futebol praticado no Brasil seria idêntico ao praticado na Alemanha, onde são valorizadas a disciplina e a obediência tática.

Os valores produzidos pelas categorias centrais do espaço de representação do futebol se articulam no interior do reino do ethos futebolístico. Parte-se do pressuposto que o futebol produz e se estrutura através de uma série de valores, que podem ser perfeitamente antagônicos. Desta forma, as decisões tomadas no reino da política institucional, as manifestações de afetividade, as relações de poder, as representações sociais do futebol, etc. se articulam a partir de uma série de valores produzidos e modificados ao longo do tempo. Alguns valores produzidos pelo futebol e/ou contemplados por ele são o de profissionalismo (e seu antagônico amadorismo), o de raça, o de democracia social e racial, o da possibilidade de ascensão social, de identificação com a pátria, entre um sem número de outros.

Os ethos de profissionalismo e amadorismo convivem no futebol brasileiro, desde seu surgimento. Atualmente, a discussão desta ética dupla se refere, sobretudo, à administração dos clubes. Alguns adotaram a administração profissional (pautada no racionalismo) em detrimento daquela amadora, baseada na estrutura tradicional de um clube (cargos não remunerados, conselheiros e diretores ligados ao clube por afetividade, etc.).

É fundamental, para se entender como afetividade é criada e se manifesta, compreender o processo de socialização tanto primária quanto secundária. Este processo é posterior à interiorização, um dos três momentos constituintes da dialética da sociedade. Os outros dois são a exteriorização e a objetivação (BERGER; LUCKMANN, 1999).

Segundo Berger e Luckmann (1999, p. 174), a interiorização é

a apreensão ou interpretação imediata de um acontecimento objetivo como dotado de sentido, isto é, como manifestação de processos subjetivos de outrem, que desta maneira torna-se subjetivamente significativo para mim.
Apesar de atribuir sentido à subjetividade do outro, o indivíduo não necessariamente o compreende adequadamente. É através da interiorização que ele toma conhecimento de seus semelhantes e do mundo como realidade social significativa.

Ao realizar o processo de interiorização, o indivíduo se torna membro da sociedade através da socialização "que pode assim ser definida como a ampla e consistente introdução de um indivíduo no mundo objetivo de uma sociedade ou de um setor dela" (BERGER; LUCKMANN, 1999, p. 175).

A socialização primária ocorre na infância e marca o processo de inserção da criança na sociedade. Ela não ocorre apenas como um processo cognoscitivo, mas também tem como elemento fundamental às emoções. É através delas que a criança se liga aos indivíduos à sua volta, possibilitando o processo de aprendizagem. Para que a criança se socialize, é preciso que ela se identifique com os significativos à sua volta, interiorizando seus papéis e atitudes, para que, assim, possa se identificar a si mesma subjetivamente de modo coerente e plausível. Desta forma, constrói sua personalidade em um processo reflexivo através de "uma dialética entre a identificação pelos outros e a auto-identificação, entre a identidade objetivamente atribuída e a identidade subjetivamente apropriada" (BERGER; LUCKMANN, 1999, p. 176-177). Todavia, a criança não somente absorve as atitudes e os papéis dos significativos à sua volta, bem como assume o mundo deles, criando uma identidade social que localiza o indivíduo (criança) neste mundo.

O processo de socialização secundária acontece posteriormente à primária. Aqui o indivíduo interioriza "submundos" institucionais, em decorrência da divisão do trabalho e da distribuição social do conhecimento. Adquire, assim, funções específicas dentro destas realidades parciais - formadas pelos "submundos" -, porém, razoavelmente coerentes e constituídas por elementos normativos, afetivos e cognoscitivos. Tais submundos necessitam ser legitimados, de forma que são freqüentemente acompanhados por símbolos, sejam eles materiais ou rituais. Como a socialização secundária depende da já realização da socialização primária, pressupõe-se um mundo já interiorizado e contornos de uma personalidade já formada. Sendo assim, se torna difícil a interiorização de novos conteúdos, pois o indivíduo já possui uma realidade arraigada, que tende a persistir. Desta forma, os novos conteúdos devem se sobrepor aos já existentes, o que não é um processo fácil.

Estes processos, de certa forma, explicam o poder de influência que os pais têm na escolha do time para o qual seus filhos vão torcer. Normalmente, a criança tende a copiar os pais e torcer para o mesmo clube, 
mas em alguns casos ocorre o oposto: a criança escoIhe um time rival para torcer justamente para buscar uma identidade própria em relação aos seus pais. Além disso, há outros fatores que influenciam na escolha, como os amigos, os resultados que os clubes apresentam (em épocas de vitórias, a tendência é que o clube aumente o número de torcedores), a mídia, entre outros.

O reino da afetividade é aquele no qual se articulam as emoções em relação ao esporte, aos clubes, e a todos os outros elementos ligados ao espaço de representação do futebol. As emoções das relações socioespaciais que o futebol promove são diversas. No entanto, no futebol se percebem manifestações de afetividade levada ao extremo, uma afetividade exaltada, a qual será chamada aqui de paixão.

A paixão pode se manifestar de várias formas: pelos clubes, seleções, jogadores, etc. Além disto, a paixão pode desencadear outros sentimentos como o ódio por outros clubes ou seleções, entre outros muitos. A paixão é estimulada desde a infância, quando a criança "escoIhe" um time para torcer. Na verdade a escolha da criança é condicionada por vários fatores e em muitos casos ela é coagida pelos pais que querem ver sua paixão continuar nos filhos. O processo de socialização primária é então fundamental na escolha de um clube, pois posteriormente é mais difícil para o indivíduo trocar de clube. Isto se deve ao fato que este fenômeno não é bem aceito socialmente. $\mathrm{O}$ indivíduo que procede assim é rotulado de "vira-casaca" e perde moral no espaço de representação do futebol. Esta paixão pelo clube é denominada de paixão clubística, que passa pela negação dos demais clubes (DAMO, 2002).

A paixão se manifesta nesta escolha e na defesa das cores do clube, ou seja, no torcer. O torcedor não é completamente racional, não enxerga os fatos com imparcialidade, pois a paixão pelo seu time o impede. Desta forma, rejeita tudo que não seja ligado ao seu clube, principalmente os outros times, pelos quais às vezes chega a cultivar ódio. As emoções permeiam todas as relações do espaço de representação do futebol de forma decisiva.

Em suma, o espaço de representação do futebol é a instância da espacialidade do futebol na vida dos indivíduos. Nele a experiência futebolística dos indivíduos é plena. Este espaço é concebido, construído, modificado e vivenciado nas relações cotidianas, através de representações sociais. No espaço de representação do futebol, os universos consensual e reificado se relacionam.
Este espaço de representação do futebol ajuda os indivíduos a dar sentido à sua vida social, pois o futebol, no Brasil, extrapola seus significados esportivos, invadindo com enorme força o campo cultural e social, construindo paisagens, relações e símbolos. Tais elementos dizem muito sobre a cultura de uma determinada sociedade, pois são produtos de tal cultura. Assim sendo, o espaço de representação do futebol não é um conceito limitado exclusivamente para o estudo do futebol como esporte, mas como expressão social e cultural, podendo ser apropriado por qualquer estudo cujo objeto é a cultura e a sociedade em nível mundial, nacional, regional, estadual ou municipal.

\section{CONSIDERAÇÕES FINAIS}

O presente artigo procurou apresentar uma alternativa teórica para o estudo do futebol sob o olhar da geografia. O tema, muitas vezes negligenciado pela academia, merece maior atenção, pois é um elemento fundamental da cultura brasileira.

O espaço de representação do futebol se apresenta, assim, como uma importante instância da espacialidade, cuja prática social se dá, fundamentalmente, no cotidiano. Mesmo assim, no espaço de representação do futebol os universos consensual e reificado coexistem. Esta prática está articulada com o fato futebolístico, elemento fundamental desta instância da espacialidade. O poder permeia todas as relações cotidianas (prática social do futebol) e ritualísticas (fato futebolístico) entre os diferentes atores socioespaciais - profissionais, especialistas e torcedores - e as instituições. A interação destes elementos gera símbolos, mitos modernos, discursos e identidades futebolísticas, os quais se manifestam como representações sociais nos reinos da política institucional, ethos futebolístico e paixão/afetividade.

A proposta de aproximação teórica entre a abordagem cultural em geografia, a teoria das representações sociais e as formulações sobre espaço de representação se mostrou efetiva, pois fundamentou um conceito capaz de apreender o futebol como um elemento sociocultural e construtor de espacialidade. Assim, alerta sobre novas possibilidades de estudos da ciência geográfica sobre temas culturais não apenas sob seus aspectos materiais como simbólicos também. 


\section{REFERÊNCIAS}

AMARAL, L. Objetividade jornalística. Porto Alegre: SagraLuzzatto, 1996.

BERGER, P. L.; LUCKMANN, T. A construção social da realidade. Petrópolis: Vozes, 1999.

CASSIRER, E. Linguagem e mito. São Paulo: Perspectiva, 1992.

O mito do estado. São Paulo: Códex, 2003.

CASTELLS, M. O poder da identidade: a era da informação, economia sociedade e cultura. v. 2. Rio de Janeiro: Paz e Terra, 2002.

CHEVALIER, J.; GHEERBRANT, A. Dicionário de símbolos. Rio de Janeiro: José Olympio, 2003.

CLAVAL, P. A Geografia Cultural: o estado da arte. In: CORRÊA, R. L.; ROSENDAHL, Z. (Orgs.). Manifestações da cultura no espaço. Rio de Janeiro: Eduerj, 1999.

2001.

A geografia cultural. Florianópolis: Editora da UFSC,

DAMO, A. S. Futebol e identidade social: uma leitura antropológica das rivalidades entre torcedores e clubes. Porto Alegre: Editora da Universidade/UFRGS, 2002.

FIFA. Mexico 1970. Disponível em: <http:// fif aworldcup.yahoo.com/ $06 /$ en/p/pwc/ph/ 1970.html?i=11\&d=1> Acesso em: 20 abr. 2005.

FOUCAULT, M. Microfísica do poder. Rio de Janeiro: Graal, 1998.

GIL FILHO, S. F. Espaço de representação: epistemologia e método. Florianópolis: Anpege, 2003.

GIULIANOTTI, R. Sociologia do futebol: dimensões históricas e socioculturais do esporte das multidões. São Paulo: Nova Alexandria, 2002.
JOVCHELOVITCH, S. Representações sociais e esfera pública: a construção simbólica dos espaços públicos no Brasil. Petrópolis: Vozes, 2000.

LECOURT, D. A arqueologia e o saber. In: ROUANET, S. P. (Org.). O homem e o discurso: a arqueologia de Michel Foucault. Rio de Janeiro: Tempo Brasileiro, 1996.

LEFÉBVRE, H. The production of space. Oxford: Blackwell, 1991.

MOSCOVICI, S. Representações sociais às representações coletivas: elementos para uma história. In: JODELET, D. (Org.). As representações sociais. Rio de Janeiro: Eduerj, 2001.

. Representações sociais: investigações em psicologia social. Petrópolis: Vozes, 2003.

PERDIGÃO, P. Anatomia de uma derrota: 16 de julho de 1950 - Brasil x Uruguai. São Paulo: L\&PM, 1986.

RAFFESTIN, C. Por uma geografia do poder. São Paulo: Ática, 1993.

SOJA, E. W. Geografias pós-modernas: a reafirmação do espaço na teoria social crítica. Rio de Janeiro: Jorge Zahar, 1993.

Thirdspace: journeys to Los Angeles and other realand-imagined places. Oxford: Blackwell, 1996.

TOLEDO, L. H. de. No país do futebol. Rio de Janeiro: Jorge Zahar, 2000.

. Lógicas no futebol. São Paulo: Hucitec/Fapesp, 2002.

UNZELTE, C. O livro de ouro do futebol. São Paulo: Ediouro, 2002. 